\title{
Medium-term effects of corn biochar addition on soil biota activities and functions in a temperate soil cropped to corn
}

Xavier Domene ${ }^{1,2,3}$, Stefania Mattana ${ }^{1}$, Kelly Hanley $^{3}$, Akio Enders $^{3}$, Johannes $^{2}$

Lehmann $^{3}$

${ }^{1}$ CREAF, Cerdanyola del Vallès 08193, Spain

${ }^{2}$ Univ Autònoma Barcelona, Cerdanyola del Vallès 08193, Spain

${ }^{3}$ Department of Crop and Soil Sciences, Cornell University, Ithaca, New York 14853,

United States

Keywords: biochar, microorganisms, soil fauna, litter, decomposition, mineralization

This is the author's version of a work that was accepted for publication in Soil biology and biochemistry. Changes resulting from the publishing process, such as peer review, editing, corrections, structural formatting, and other quality control mechanisms may not be reflected in this document. Changes may have been made to this work since it was submitted for publication. A definitive version was subsequently published in Domene, $\mathrm{X}$ and Mattana, S. "Medium-term effects of corn biochar addition on soil biota activities and functions in a temperate soil cropped to corn" in Soil biology and biochemistry, vol. 72 (May 2014), p. 152-162. DOI 10.1016/j.soilbio.2014.01.035 


\section{ABSTRACT}

Biochar addition to soil has been generally associated with crop yield increases observed in some soils, and increased nutrient availability is one of the mechanisms proposed. Any impact of biochar on soil organisms can potentially translate to changes in nutrient availability and crop productivity, possibly explaining some of the beneficial and detrimental yield effects reported in literature. Therefore, the main aim of this study was to assess the medium-term impact of biochar addition on microbial and faunal activities in a temperate soil cropped to corn and the consequences for their main functions, litter decomposition and mineralization. Biochar was added to a corn field at rates of $0,3,12,30$ tons ha $^{-1}$ three years prior to this study, in comparison to an annual application of $1 \mathrm{t} \mathrm{ha}^{-1}$.

Biochar application increased microbial abundance, which nearly doubled at the highest addition rate, while mesofauna activity, and litter decomposition facilitated by mesofauna were not increased significantly but were positively influenced by biochar addition when these responses were modeled, and in the last case directly and positively associated to the higher microbial abundance. In addition, in short-term laboratory experiments after the addition of litter, biochar presence increased $\mathrm{NO}_{2}+\mathrm{NO}_{3}$ mineralization, and decreased that of $\mathrm{SO}_{4}$ and $\mathrm{Cl}$. However, those nutrient effects were not shown to be of concern at the field scale, where only some significant increases in SOC, $\mathrm{pH}, \mathrm{Cl}$ and $\mathrm{PO}_{4}$ were observed.

Therefore, no negative impacts in the soil biota activities and functions assessed were observed for the tested alkaline biochar after three years of the application, although this trend needs to be verified for other soil and biochar types. 


\section{INTRODUCTION}

Biochar is a carbon(C) -rich product obtained by thermal decomposition of biomass at relatively low temperatures $\left(<700^{\circ} \mathrm{C}\right)$ and low oxygen concentration, in a process known as pyrolysis. During this process heat, flammable gases and liquids are produced together with a solid residue, biochar. The process resembles traditional charcoal production, but biochar is used as a soil amendment and not for energy generation (Lehmann and Joseph 2009). More recently, biochar has been more narrowly defined in terms of its capacity to sequester $C$ and improve soil functions (Verheijen et al. 2010). Due to its particulate nature and its chemical structure, biochar is more stable than any other organic amendment which provides high recalcitrance to microbial decomposition (Spokas 2010), which has led to the consideration of biochar production as a C-negative technology for climate change mitigation (Woolf et al. 2010). Biochar application to soil and knowledge of its benefits to improve soil fertility is not new and has been practiced in traditional agriculture in many regions (Ogawa and Okimori 2010). However, the recent activity in biochar research and development has generated broad interest that has lead to a rapid spread of the technology.

Biochar is able to improve soil fertility in some soils (Verheijen et al. 2010, Jeffery et al. 2011, Kookana et al. 2011, Spokas et al. 2012, Biederman and Harpole 2013) as a result of its effects on physico-chemical and biological properties. Biochar has been shown to improve water retention, aggregation and permeability in some soils (Downie et al. 2009, Busscher et al. 2010, Liu et al. 2012), or increase the pH of acid soil (Jeffery et al. 2011), as well as increase plant nutrient availability in nutrient-limited agroecosystems (Major et al. 2010). Various mechanisms have been suggested for the latter such as: (1) the initial addition of soluble nutrients contained in the biochar (Sohi et al. 2010) and the mineralization of the labile fraction of biochar containing organically bound nutrients (Lehmann et al. 2009); (2) reduced nutrient leaching due to biochars' high cation exchange capacity (Liang et al. 2006; Cheng et al. 2008, 
Laird et al. 2010, Spokas et al. 2012); (3) lower gaseous $N$ losses by ammonia volatilization (Taghizadeh-Toosi et al. 2012) and $\mathrm{N}_{2}$ and $\mathrm{N}_{2} \mathrm{O}$ by denitrification (Cayuela et al. 2013); and (4) a retention of N, P and S associated with the increase in biological activities and/or community shifts (Pietikäinen et al. 2000, Thies and Rillig 2009, Lehmann et al. 2011; Güereña et al. 2013). Some of these mechanisms involve soil biota, and this is why effects on soil fauna might translate into changes in nutrient availability (Altieri 1999, Lavelle et al 2006). Despite this fact, effects on soil biota are one of the most understudied topics in biochar research (Lehmann et al. 2011), and many of the observed effects may be explainable with changes in soil biota.

In agroecosystems decomposer microorganisms are essential for nutrient release from soil organic matter to sustain crop production in addition to the inputs of fertilizers (Bardgett 2005). If biochar causes shifts in microbial communities, $C$ cycling can also be affected (Nielsen et al. 2011), as well as other nutrients, and influence primary production or the fauna relying on microbiota. Not only changes in microorganism activity, but that of any soil biota group may have effects on other groups due to the complexity of below-ground food webs (Bardgett 2005). Therefore, an understanding of biochar effects on the interaction between a range of soil biota groups is needed.

Research on the effects of biochar on soil biota has been largely restricted to soil microbial abundance and activity. The change of the physicochemical environment, such as increased water and nutrient retention, and the provision of a refuge habitat protecting microorganisms from predators have been proposed as mechanisms (Lehmann et al. 2011, Ennis et al. 2012). However, studies on the impact on other biological groups are scarce in the scientific literature, especially with respect to soil fauna (Lehmann et al. 2011). In addition,the consequences of such impacts on soil functions such as decomposition and mineralization are poorly understood. It has been hypothesized that biochar might positively affect soil biota through the increase in soil aggregation and porosity, $\mathrm{pH}$, moisture retention and soil temperature, as well as 
nutrient retention (McCormack et al. 2013), although negative effects might be also be expected with an enhanced retention of toxic substances, such as ammonium and pesticides (Ennis et al. 2012, McCormack et al. 2013), and the release of pollutants from biochar, such as pyrolysis oils (Gell et al. 2011) and PAH (Hale et al. 2012). Currently there is a need for demonstration of the environmental benefits of biochar while avoiding detrimental effects on environmental health (Verheijen et al. 2010). Some biochars might pose a direct risk to soil biota and their functions (Liesch et al. 2010, Weyers and Spokas 2011), and may explain some of the negative crop yields reported in literature (Spokas et al. 2012).

The aim of our study is assessing the medium-term effects of biochar additions on microbial and faunal activity and their main soil functions, decomposition and mineralization.

\section{METHODS}

\subsection{Experimental plots}

The experimental plots were located at Cornell University's Musgrave Research Farm in Aurora, NY, USA (42043'48.64"N, 76³9'16.03"W), continuously cropped to corn for more than 30 years in a soil and with an experimental design described in detail by Güereña et al. (2013). The experimental site was divided into plots of $4.5 \times 7.5 \mathrm{~m}$ (33.7 $\mathrm{m}^{2}$ ), with a 2-m buffer strip between them. Three plots were prepared per biochar addition rate in a completely randomized design. In April 2007, biochar was applied before planting, at rates of $0,3,12,30 \mathrm{tha}^{-1}$. In addition, an annual application of $1 \mathrm{t}$ $\mathrm{ha}^{-1}$ was tested using the same batch of biochar (applied in 2007, 2008, and 2010, but not in 2009). Biochar was incorporated to plots by hand rake and shovel to a depth of approximately $50 \mathrm{~mm}$ which was then followed by mechanical tillage to about $0.13 \mathrm{~m}$ uniformly for all treatments. 
The biochar was produced from corn stover by slow pyrolysis (30 min, $600^{\circ} \mathrm{C}$ ) at BEST Energies Inc. (Somersby, Australia), and its properties are described in Güereña et al. (2013). The ecotoxicological characterization of this biochar demonstrated no inhibition for the reproduction of soil collembolans (ISO 1999) and enchytraeids (ISO 2004) in soil-fresh biochar mixtures ( 0.2 to $14 \%, w / w)$ after $28 \mathrm{~d}$ of exposure (data no shown).

In the 2010 growing season of this study, three years after the application of biochar, a NPK fertilizer (10-20-20) was applied at planting (mid-May) at a rate of $12.3 \mathrm{~kg} \mathrm{~N} \mathrm{ha}^{-1}$. Three weeks after planting (early July), a secondary fertilization was applied at rates of $100.8 \mathrm{~kg} \mathrm{~N} \mathrm{ha}^{-1}$ (corresponding to $90 \%$ of the recommended $\mathrm{N}$ application rate).

Plots were sown with a maize crop (Pioneer Hybrid 38M60 Triple stack, Pioneer HiBred International, Inc., Johnston, IA, USA), at a rate of 79,287 seeds ha ${ }^{-1}$. No pesticides were applied that year with the exception of pre-emergence herbicides applied just after sowing (atrazine and Lumax®), since a genetically modified and insect resistant corn variety was used. Exposure to genetically modified corn in field conditions has not been linked to detrimental effects on soil invertebrates or functions such as decomposition (Cortet et al. 2006, Hönemann et al. 2008, Tarkalson et al. 2008).

\subsection{Soil physicochemical properties}

Soil sampling was performed in summer 2010, three weeks after the secondary fertilization (late July), and in early fall (late September), which corresponded to the initial growth and the senescence of corn plants, respectively. Samples were taken in the four central rows of the plot using a metal core with a diameter of $45 \mathrm{~mm}$ diameter and length of $0.1 \mathrm{~m}$. Three composite samples were taken per plot, each obtained from three soil cores. 
The soil particle-distribution and texture were assessed in air-dried samples by the pipette method (Gee and Bauder 1986). The soil organic C (SOC) content was measured by the Walkley-Black procedure (Nelson and Sommers 1982). This method does not fully reflect $C$ content of biochars (Manning et al. 2009), but the more labile fraction (Calvelo Pereira et al. 2011), hence potentially quantifying the most biologically relevant $\mathrm{C}$ fraction of biochars, potentially mineralizable by microorganisms which in turn could also affect other biological groups and soil functions.

The remaining soil properties were measured in an aqueous extract, where $25 \mathrm{~g}$ of fresh soil were mixed with $100 \mathrm{ml}$ of deionised water and horizontally shaken at 160 rpm for 30 min. After that, soil particles were left to settle for $1 \mathrm{~min}$, and the liquid phase was centrifuged for $5 \mathrm{~min}$ at $3600 \mathrm{xg}$. Then the supernatant was gravimetrically filtered (Whatman 1). Half of the extract was used for immediate measurement of $\mathrm{pH}$ and electrical conductivity (EC), while the other half was used for quantification of the ionic content $\left(\mathrm{NO}_{2}, \mathrm{NO}_{3}, \mathrm{NH}_{4}, \mathrm{PO}_{4}, \mathrm{SO}_{4}\right.$ and $\left.\mathrm{Cl}\right)$. For practical reasons, the extract for the last analysis was stored at $-20^{\circ} \mathrm{C}$ just after its preparation until the day of the analysis. Simultaneously, $20 \mathrm{~g}$ of the same fresh soil was weighed and dried at $105^{\circ} \mathrm{C}$ for $12 \mathrm{~h}$ for assessment of the moisture content. Soil $\mathrm{pH}$ and EC were measured by potentiometry in an Orion 3-Star pH meter and an Orion 115 Aplus Conductivity Meter (Thermo Scientific Waltham, MA, USA), respectively.

In the summer sampling, soluble $\mathrm{NO}_{2}, \mathrm{NO}_{3}, \mathrm{Cl}$ and $\mathrm{SO}_{4}$ were assessed by ionic chromatography (RFC 2000, Dionex) while $\mathrm{PO}_{4}$ and $\mathrm{NH}_{4}$ were measured using a flow analyzer (FS 3000, OI Corporation) by the ascorbic acid and ammonium molybdate method (Murphy and Riley 1962), and the phenate method (APHA 1985), respectively. In the fall sampling, all the ions were measured by ionic chromatography (DX-100, Dionex). 


\subsection{Microorganism abundance, activity and efficiency}

In summer 2010 (early July), fifteen soil cores with a diameter of $45 \mathrm{~mm}$ and a length of $0.1 \mathrm{~m}$ were taken per plot and stored separately. In the laboratory, composite samples were prepared, each containing three randomly selected cores, thereafter used for the assessment of microbial biomass (MCB) in duplicate, and the soil basal respiration (BAS) in triplicate.

MCB was taken as a measure of microbial abundance, and was measured by the fumigation-extraction method (Brookes and Joergensen 2006). The uncorrected MCB values were multiplied by a correction factor obtained from the dataset in Jin (2010), in a study carried out in the same plots, to account for the underestimation of MCB due to the sorption of cell lysates to biochar (Liang et al. 2010). Namely, the correction factor was $1.53,1.55,1.62$, and 1.77 for the plots with $0,3,12$ and 30 tons $^{-1}$ application rate, respectively, and 1.55 for the plots with the annual $1 \mathrm{t} \mathrm{ha} \mathrm{a}^{-1}$ application.

BAS was measured according to Pell et al. (2006) after $24 \mathrm{~h}$ of incubation at $20^{\circ} \mathrm{C}$, and taken as measure of total microbial activity. The $\mathrm{C}$ mineralization coefficient (CMC), expressed as the ratio of BAS to the summer organic C values was also calculated, and taken as a standardized measurement of microbial activity.

Microorganisms C-use efficiency was assessed by the metabolic quotient $\left(\mathrm{qCO}_{2}\right)$, obtained from the BAS/MCB ratio, which has been suggested as an indicator of the energetic efficiency of the community and hence of the succession and stabilization of the community after a disturbance (Anderson and Domsch 1990), as well a measure of microbial community stress (Wardle and Ghani 1995).

\subsection{Fauna activity}


Fauna feeding rates were assessed by the bait lamina method (von Törne 1990) using bait-lamina purchased from Terra Protecta GmbH (Berlin, Germany). The method is sensitive to variation in soil faunal activity after anthropogenic impacts such as pollution (Filzek et al. 2004, Hartley et al. 2008), or agricultural management practices (Reinecke et al. 2008). Some degree of microbial decomposition of the bait could be expected (Von Törne 1990, Kratz 1998), but it mainly reflects fauna feeding activity, such as that of collembolans and enchytraeids (Helling et al. 1998, Gongalsky et al. 2008), but also earthworms (Van Gestel et al. 2003, Förster et al. 2004, Hamel et al. 2007, Gongalsky et al. 2008).

Bait-lamina consisted of a 160-mm PVC stripe with 16 consecutive holes filled with a mixture of cellulose powder and bran flakes $(7: 3, w / w)$, and traces of activated carbon (Kratz 1998). Feeding activity was assessed as bait consumption one or two weeks after inserting it into the soil. Total feeding rates, as well as the depth-specific rates (0$30,30-60,60-80 \mathrm{~mm}$-depth), were investigated. Feeding activity was assessed as qualitative feeding (percent of holes showing any degree of bait consumption) and as quantitative feeding (mean intensity of such consumption, visually assessed in each hole as $0,10,25,50,75$ and $100 \%)$.

The summer sampling was carried out at the beginning of the cropping season (early July 2010), and the fall sampling at the end of the cropping season (late September 2010). In summer, seven bait laminae were inserted per plot in the four central interrows between corn plants, and removed 20 days later due to dry and hot weather during the first week. In fall, bait laminae numbers were increased to twelve per plot and removed after 7 days. After sampling, laminae were immediately transported to the laboratory and visually assessed. 


\subsection{Litter decomposition}

Decomposition was assessed in 2-mm and 0.16-mm mesh litterbags, consisting of two $0.2 \times 0.2 \mathrm{~m}$ squares, bent and stapled laterally to avoid litter losses. The 0.2-mm mesh corresponded to a regular PVC insect screen, while the $0.16-\mathrm{mm}$ mesh corresponded to a polyester Accu-Mesh® 160 microns white screen mesh (Alpha Screens \& Supplies Inc, Hicksville, NY). The 2-mm mesh bags assess decomposition resulting from the combined action of microorganisms, microfauna and mesofauna, while the 0.16-mm mesh only accounts for the decomposition due to microorganisms and microfauna (Bradford et al. 2002).

Each bag was filled with $5 \mathrm{~g}$ of corn stover, the same used for the mineralization tests, consisting of a mixture of leaves and stalks collected in the same plots in the 2009 harvest, then dried at $70^{\circ} \mathrm{C}$ for $24 \mathrm{~h}$, and sieved to $15.9-4.76 \mathrm{~mm}$ to avoid losses through the bag's mesh. The use of corn stover was intentional in order to mimic the actual plant litter, as recommended for the litterbag method (Knacker et al. 2003).

In late June 2010, eight 50-mm deep soil holes were prepared in the four central interrows of each plot. In each hole, one 2-mm and one 0.16-mm mesh litterbag were buried side-by-side. After 3 months, all the bags were removed, hence covering most of the growing season of the crop, and immediately transported to the laboratory. Each litterbag was rinsed in tap water to remove soil particles, dried at $70^{\circ} \mathrm{C}$ for $12 \mathrm{~h}$ and its content weighed.

\subsection{Mineralization studies}

Mineralization after litter addition to soil was assessed by adapting the OECD C mineralization test (OECD 2000a) and the $\mathrm{N}$ mineralization test (OECD 2000b), designed to assess the effects of pollution, to the purpose of this study, which was the 
laboratory assessment of the $\mathrm{C}, \mathrm{N}, \mathrm{P}, \mathrm{S}$ and $\mathrm{Cl}$ mineralization in soil samples taken from the field plots after the addition of corn stover.

Three soil cores (diameter of $45 \mathrm{~mm}$ and a length of $0.1 \mathrm{~m}$ ) were randomly taken in each plot in late July and immediately transported to the laboratory. Soil samples were kept in the dark at $20^{\circ} \mathrm{C}$ in sealed flasks, to avoid drying, and aerated twice per week to ensure oxygen supply, while a subsample of each soil column was used to assess their moisture and the maximum water holding capacity (WHC). After one week, soil column moisture was adjusted to $40 \%$ of the WHC. The day after, the same corn stover used in the litterbag experiment, but finely ground, was added at a rate of $0.15 \%$ (equivalent to a 3 t stover ha-1), only slightly above the range of the stover inputs in corn crops reported by Mann et al. (2002). Then, nine subreplicates were prepared from each soil column to allow the destructive sampling of three replicates after 7,14 and 28 days of incubation. Each replicate consisted of a $125 \mathrm{ml}$ flask filled with $25 \mathrm{~g}$ of fresh soil. The $\mathrm{CO}_{2}$ release in each subreplicate was measured by the method already described for BAS, and then the same subreplicate was used to prepare the aqueous extracts for the ionic content assessment. Water soluble $\mathrm{NO}_{2}, \mathrm{NO}_{3}, \mathrm{NH}_{4}, \mathrm{PO}_{4}, \mathrm{SO}_{4}$, and $\mathrm{Cl}$ were measured by ion chromatography as described above. In order to avoid any bias of the initial mineralization products as well as its retention by biochar, mineralization was expressed as net mineralization rate. More precisely, for each mineralization product and replicate, concentrations were plotted against days of incubation and the slope obtained after linear regression was taken as mineralization rate. $\mathrm{NO}_{2}$ and $\mathrm{NO}_{3}$ concentrations were combined for the calculation of mineralization rates, since $\mathrm{NO}_{2}$ is transient in soil under aerobic conditions and quickly converted to $\mathrm{NO}_{3}$ (Burns et al. 1996).

Although mineralization products measured in our study might also come from native organic matter or from biochar mineralization itself (Keith et al. 2011), most of the 
nutrients released should come from stover. Furthermore, we consider water extracts to be representative of the most bioavailable fraction for plants and soil biota.

\subsection{Statistical analysis}

All statistical analyses were carried out using R software version 2.15.0 ( $R$

Development Core Team 2012). Several measurements were carried out within each plot, but only the mean value per plot was used for the statistical analysis, preventing pseudoreplication. A General Linear Model (Im function in R software), including biochar application rate as a factor, was used to test differences by biochar application rates compared to control plots, followed by a one-way ANOVA of this model to assess global differences (anova function of the R software). For variables with two sampling events, separate analyses were carried out for summer and fall data, as well for the mean annual values.

Pairwise correlations between measured response and explanatory variables were assessed by Pearson correlations (cor function in R software). For the annual biochar application of $1 \mathrm{t} \mathrm{ha}^{-1}$, the value used for correlations was $3 \mathrm{t} \mathrm{ha}^{-1}$, since this was the cumulative amount applied at the moment of the study since the first application in 2007.

The response variables (MCB, $\mathrm{BAS}, \mathrm{CMC}, \mathrm{qCO}_{2}$, fauna feeding, decomposition and mineralization rates) were modeled using Generalized Linear Models (GLM) as a function of the explanatory variables (biochar application rate together with all the physical, chemical and biological soil properties measured). GLM were constructed using identity as link function, and assuming Gaussian distribution of the response variables ( $g / m$ function of the R software). An initial global model including all the variables was constructed, and then all the possible models, restricted to three explanatory variables at most, were constructed and arranged from the best to the 
worst goodness of fit (lowest AICc). AICc corresponds to a corrected Akaike information criterion, suitable for small sample sizes or high number of parameters in the model, which is the case of our dataset. This best model selection was carried out using the dredge function of the MuMIn package of the R software (Barton 2007).

\section{RESULTS}

\subsection{Soil physicochemical properties}

Particle-size distribution and soil moisture characteristics were not significantly affected by biochar additions irrespective of application rates, indicating a homogeneous texture in the experimental plots (Supplementary Table S1, Figure 1). SOC values were only significantly higher with an application rate of $12 \mathrm{t} \mathrm{ha}^{-1}$ in summer $(\mathrm{p}=0.049)$ compared to control plots, but not in fall. In summer, $\mathrm{pH}$ values were significantly higher at all biochar rates compared to control plots, while no differences were observed in fall (Figure 1). Acccordingly, a positive correlation between biochar rate and summer $\mathrm{pH}$ was observed $(0.005 \mathrm{pH}$ units per ton of biochar, $r=0.57, \mathrm{p}=0.02$, data not shown). When the mean annual values were compared individually, only the annual $1 \mathrm{t} \mathrm{ha}^{-1}$ addition rate and the $30 \mathrm{t} \mathrm{ha}^{-1}$ addition rate showed significant $\mathrm{pH}$ increases (2.4 and 2.8\%, respectively) compared to control plots (Supplementary Table S1). EC, $\mathrm{NO}_{2}$, $\mathrm{NO}_{3}, \mathrm{NH}_{4}$ and $\mathrm{SO}_{4}$ values did not differ in biochar-amended plots compared to control plots, neither in summer or fall (Figure 1), nor in the mean annual values (Supplementary Table S1), but increased $\mathrm{PO}_{4}$ was observed in the fall sampling with annual biochar applications (Supplementary Figure S1). Furthermore, significant positive correlations were detected between biochar application rate and summer $\mathrm{PO}_{4}$ and fall $\mathrm{Cl}(\mathrm{r}=0.74$ and 0.61 respectively, data not shown). 


\subsection{Microorganism abundance, activity and efficiency}

$\mathrm{BAS}, \mathrm{CMC}$ and $\mathrm{qCO}_{2}$ did not significantly vary with different application rates when compared to control plots. MCB, however, was significantly higher with an addition of $30 \mathrm{t} \mathrm{ha}^{-1}$ biochar compared to controls $(\mathrm{p}=0.03$ ) (Table 1, Figure 2$)$, and was positively correlated with biochar application rates $(r=0.60, p=0.01$, data not shown). However, we cannot discard significant changes in $\mathrm{CMC}$ and $\mathrm{qCO}_{2}$, since the small sample size and high within-group variability may cause a type II error, i.e. failure to reject the null hypothesis that the means of the groups are equal when the alternative hypothesis is true.

The models for logMCB, BAS, $\mathrm{CMC}$ and $\mathrm{qCO}_{2}$ accounted for $56,62,14$ and $68 \%$ of the observed variance, respectively. The model derived for MCB only included moisture as an explanatory parameter (Supplementary Table S2), indicating higher MCB with higher moisture, while biochar application rate was not included. In the model for BAS only soil texture was included, while the model derived for $\mathrm{CMC}$ was not acceptable due its low predictability and because the only parameter included was not significant by itself. Finally, the model for $\mathrm{qCO}_{2}$ included moisture and $\mathrm{SOC}$ as positive parameters, and sand content as a negative parameter, although SOC was not in itself significant.

\subsection{Fauna feeding activity}

No significant differences in the feeding rates were found between biochar-added plots and controls, irrespective of season (Figure 3, Table 1) nor were correlations with rates of application significant (Supplementary Table S3). Although a type II error might be also suspected due to the high variability in this response, modeling of summer feeding rates showed that only soil texture, together with other physicochemical properties, explained the variation in feeding rates observed between 
plots but not biochar additions (Supplementary Table S4). Hence, feeding was almost entirely explained by soil texture, with the only exception of the qualitative summer feeding rates at 30-60 mm-depth, which appeared to be also positively influenced by MCB and soil SOC, and negatively by $\mathrm{PO}_{4}{ }^{3-}$. The models derived for summer feeding rates explained between 52 and $77 \%$ of the variance observed. In the fall feeding rates, more consistent trends were found, with a positive effect of biochar in some of the models (although this parameter was not significant by itself in some cases) and a general negative contribution of loam contents (Supplementary Table S4). The models for fall feeding rates explained between 53 and $69 \%$ of the variance.

\subsection{Litter decomposition}

No differences were found in decomposition rates assessed with litter bags whether or not biochar had been added to soil, for any of the mesh sizes (Figure 4, Table 1), and no direct correlations were found between decomposition and biochar addition rates, probably related to the high variability in these response that makes a type II error plausible (Supplementary Table S3). In the 2-mm mesh bags, significant positive correlations were found between decomposition and logMCB ( $r=0.59)$, and a negative correlation with qCO2 ( $r=-0.71)$ (Supplementary Table S3). However, when the 2-mm mesh bags decomposition was modeled, biochar and $\mathrm{pH}$ were shown to have a positive effect on this response variable, and $\mathrm{Cl}$ a negative effect (explaining $72 \%$ of the variance;Supplementary Table S5). In the $0.16-\mathrm{mm}$ mesh bags, the decomposition model, explaining $74 \%$ of the variance, included a positive contribution of $\log \mathrm{MCB}$, clay and SOC, but not of the biochar application rate (Supplementary

\section{Table S5).}




\subsection{Mineralization studies}

Positive mineralization rate values indicate an increase of mineralization products over time, while negative values indicate a decrease, in relation to the initial contents. None of the mineralization products assessed showed significantly different values in biochar-added plots compared to controls, with the exception of $\mathrm{Cl}$ and $\mathrm{SO}_{4}$, showing negative rates in all the biochar addition rates and the $30 \mathrm{t} \mathrm{ha}^{-1}$ addition, respectively (Figure 5). In $\mathrm{NO}_{2}+\mathrm{NO}_{3}$ and $\mathrm{PO}_{4}$ mineralization, the lack of significant effects might be also due to a type II error. However, when correlations with biochar addition rate were sought, only a positive correlation with $\mathrm{NO}_{2}+\mathrm{NO}_{3}$ mineralization rates was found (Supplementary Table S3). The models derived for the mineralization rates also showed a general lack of effect of biochar addition rate (Supplementary Table S6). Models derived for $\mathrm{PO}_{4}$ and $\mathrm{NO}_{2}+\mathrm{NO}_{3}$ showed very low predictability. Only the models obtained for $\mathrm{Cl}, \mathrm{NH}_{4}, \mathrm{SO}_{4}$ and $\mathrm{CO}_{2}$, showed a relatively high predictability $(76,70,57$ and $51 \%$ of the variance observed), some including $\mathrm{pH}$ as a negative parameter $(\mathrm{Cl}$ and $\mathrm{SO}_{4}$ models) and soluble $\mathrm{PO}_{4}$ as a positive parameter ( $\mathrm{Cl}$ and $\mathrm{NH}_{4}$ models), but also $\mathrm{MCB}$ in the case the $\mathrm{CO}_{2}$ and $\mathrm{NH}_{4}$ models.

\section{DISCUSSION}

\subsection{Biochar effects on soil biota}

\subsubsection{Effects on microbial abundance, activity and C-use efficiency}

The increased microbial abundance after three years of biochar additions is in accordance with a study carried out in the same plots after 6 months of the application (Jin 2010) and with other published studies (Lehmann et al. 2011). Several hypotheses have been proposed to explain this fact, such as an enhanced habitat 
suitability and refuge (Pietikäinen et al. 2000, Warnock et al. 2007, Thies and Rillig 2009), less competition (Lehmann et al. 2011), higher availability of nutrients or labile organic matter on biochar surfaces (Pietikäinen et al. 2000, Bruun et al. 2009, Lehmann et al. 2011), positive priming (Zimmerman et al. 2011), or changed physical properties that increased water retention and aeration (Wardle et al. 1999, Schimel et al. 2007, Thies and Rillig 2009, Lehmann et al. 2011). In our study, moisture was the main explanation for increased $\mathrm{MCB}$, as shown by its strong positive correlation with biochar application rates ( $r=0.75$, data not shown), as well as by the model derived for MCB, where soil moisture is the only parameter included (SupplementaryTable S2).

In contrast, the absence of changes in microbial activity, when measured as BAS, indicates that net microbial processing of organic $\mathrm{C}$ did not change with application of biochar but rather with differences in soil texture. This result is in agreement with other long-term studies under field conditions were no change or even lower respiration rates were observed in biochar-amended plots, and contrasts with short-term effects just after the application of biochars, generally associated to increased respiration rates associated with the easily mineralizable organic content of fresh biochars (see Lehmann et al. 2011, Woolf and Lehmann 2012 for reviews on this topic).

The positive correlation of decomposition in the 2-mm mesh bags with MCB (in turn positively explained by biochar application rate) and the negative association with $\mathrm{qCO}_{2}$ (Supplementary Table S3), though not directly linked to biochar application rates, suggest shifts in the microbial community composition to more efficient communities that favor decomposition. This is corroborated by a previous study carried out in the same plots shortly after the biochar addition (Jin 2010), where an increased abundance of highly efficient decomposers such as fungi was observed. Although we lack direct data, this explanation might be coherent with the inclusion of $\mathrm{pH}$ as being important to decomposition in the 2-mm mesh bags, since the liming effect of biochars has been suggested to cause a shift to lower bacteria-to-fungi ratios therefore favoring 
fungivore fauna over microbivore ones (McCormack et al. 2013). Even though soil in our plots already had a pH around 7, it is interesting to note that lower bacteria-to-fungi ratios were found in the 12 and $30 \mathrm{t} \mathrm{ha}^{-1}$ plots in a previous study carried out one year after biochar application (Jin 2010).

\subsubsection{Effects on fauna activity}

Fauna feeding activity was not directly affected by biochar applications, in spite of the observed changes in both microbial biomass and soil pH. Higher microbial biomass is expected to translate into increased microbial grazer populations and from them to predators, as shown in microcosm experiments (Cole et al. 2004). Similarly, a potential stimulation of soil fauna with $\mathrm{pH}$ increase after biochar addition suggested by McCormack et al. (2013) is also limited in our plots due to the already relatively high $\mathrm{pH}$ of the soil in this study $(\mathrm{pH}=7)$. On the other hand, excessive increases in $\mathrm{pH}$ might reduce the abundance of faunal groups such as collembolans, mites or earthworms and enchytreids and change the entire soil community and their functions (Bardgett 2005, McCormack et al. 2013) which again does not seem to be the case for our plots. Accordingly, no significant variation in fauna activity was observed with corn biochar additions, and any observed changes were mostly related to soil texture. Coarse soil particles and soil particle aggregation processes are directly related to soil porosity, a key property for fauna movement and performance in soil (Lavelle et al. 2006). Also, microbial biomass was included as a positive parameter in one of the summer models, as well as biochar rate in some of the fall models, which suggests that soil fauna activity increases are also partly explained by increased food availability with biochar addition, since as previously reported, MCB was positively correlated with biochar addition. 


\subsection{Biochar effects on biota-mediated soil functions}

\subsubsection{Litter decomposition}

The observed lack of direct effects of biochar on field litter decomposition and laboratory $\mathrm{C}$ mineralization after the addition of litter is consistent with the general lack of effects on microbial and faunal activities three years after application of biochar. Similarly, the model for microbial and microfauna decomposition without the regulatory effect of mesofauna (that of the 0.16-mm mesh litterbags), did not include biochar, but included a positive contribution of $\mathrm{MCB}$ and SOC, which in turn we observed to be associated with the biochar addition application rate. In contrast, the model for decomposition rates with access by mesofauna (2-mm mesh litterbags), included biochar addition as a positive parameter, which is not in agreement with the general lack of biochar effects on fauna activity. Therefore, a minor effect on enhancing litter decomposition by soil fauna through the presence of the tested biochar in our study cannot be excluded.

\subsubsection{Mineralization}

In contrast to our findings of increased $\mathrm{N}$-mineralization with the increasing biochar addition in our aged biochar plot samples, decreased nitrate contents have typically been explained as a result of increased microbial biomass and $\mathrm{N}$ assimilation shortly after the application of fresh biochars with high labile C contents (Bruun et al. 2009, Deenik et al. 2010, Clough et al. 2013). The mechanisms for increased Nmineralization in our study are unknown, but this trend is probably transient and may be restricted to the conditions of a pot experiment, as this was not observed at the field scale. The observed lack of greater extractable $\mathrm{NO}_{3}$ in the biochar-added plots at the field scale may be partly explained by biochar's poor anion retention (Lehmann et al. 2003, Hale et al. 2013, Hollister et al. 2013). Despite a typically high CEC of biochars 
and observed $\mathrm{N}$ retention (Steiner et al. 2008), $\mathrm{NH}_{4}$ did not accrue in topsoils which agrees with Güereña et al. (2013), who quantified extractable mineral N in the same experiment in fall 2009. Even with lower $\mathrm{N}$ leaching (Major et al. 2010), extractable mineral $\mathrm{N}$ may not accumulate in soil, either because of greater plant $\mathrm{N}$ uptake (Major et al. 2012) or incorporation in organic N (Güereña et al. 2013).

The influence of biochar on S and $\mathrm{Cl}$-mineralization in soil has received little or no attention in literature (DeLuca et al. 2009) despite the role of such compounds in primary production (McGrath et al. 1996, Öberg 2002), and the decreased S and $\mathrm{Cl}$ mineralization rates observed with biochar in this study have not been reported previously.

Regarding S mineralization, an increased $\mathrm{S}$ assimilation by microorganisms or shifts in microbial community composition could be potential explanations in our enclosed incubations (DeLuca et al. 2009), since fresh biochars have been shown to release significant amounts of soluble inorganic S (Uchimiya et al. 2010, Churka-Blum et al. 2013) and $\mathrm{SO}_{4}$ retention in biochar is negligible (Borchard et al. 2012). Even though $\mathrm{S}$ is present as inorganic salts in fresh biochars and is readily released shortly after its addition to soil, $\mathrm{S}$ concentrations did not increase with biochar additions at the field scale after three years of the application, at least partly due to its ease of leaching.

The positive correlation with biochar application rates observed for $\mathrm{Cl}$ at the field scale (data not shown), is probably a result of the initial application of the corn stover biochar, typically containing significant amounts of $\mathrm{Cl}$ (Johansen et al. 2011, Rahim et al. 2013). Some studies have linked $\mathrm{Cl}$ addition to soil with nitrification inhibition (Belser and Mays 1980, Bauhus et al. 1996), but in our study the increased field $\mathrm{Cl}$ concentrations with biochar application were not related with a nitrification reduction. The same trend was observed in the laboratory, where nitrification rate was uncorrelated to $\mathrm{Cl}$ mineralization rates. 
None of the short-term nutrient mineralization effects observed in the laboratory pot experiments were translated to differential soluble ion contents at the field scale, hence suggesting these effects to be transient or counteracted by other processes such as rainfall, plant uptake, or nutrient gaseous losses that also contribute to the observed soluble ion contents.

\section{CONCLUSIONS}

The medium-term effects of biochar on soil biota in the studied sandy loam soil in a temperate climate were restricted to the higher microbial abundance without increases in microbial activity, as already reported in the same plots shortly after the addition of biochar, although a positive contribution of biochar was also shown for mesofauna activity and litter decomposition facilitated by mesofauna after modeling of those responses. The observed changes in nutrient dynamics were likely related to salt effects in short-term laboratory studies which have significance for use of biochar in growing media or potting soil, but were not shown to be of concern under field conditions. The interactions between microbial dynamics and faunal activity warrants further research, and information about faunal abundance and composition may prove rewarding. No concern about the use of the tested alkaline biochar in the studied temperate soil emanated from the reported experiments after three years, but has to be verified for other soil and biochar types.

\section{Acknowledgments}

This study has been funded by the Spanish Ministry of Science and Innovation through the CARBONET project (MICINN, CGL2010-15766), while the field plot construction and maintenance was funded by the United States Department of Agriculture through a 
Hatch grant (USDA, NY-125487), the New York State Energy Research and Development Authority (NYSERDA contract 9891), and the National Science Foundation's Basic Research for Enabling Agricultural Development (NSF-BREAD, grant number IOS-0965336).

\section{REFERENCES}

1. Anderson, TH., Domsch, K.H. 1990. The metabolic quotient for $\mathrm{CO}_{2}\left(q \mathrm{qCO}_{2}\right)$ as a specific activity parameter to assess the effects of environmental conditions, such as $\mathrm{pH}$, on the microbial biomass of forest soils. Soil Biology and Biochemistry 25, 393-395.

2. APHA (American Public Health Association), 1985. Standard Methods for the Examination of Water and Wastewater. 16th Edition. APHA, AWWA, WPCF, Washington, D.C, USA.

3. Manning, D.A.C, Lopez-Capel, E., 2009. Test procedures for determining the quantity of biochar within soils, in: Lehmann, J., Joseph, S. (Eds.), Biochar for environmental management: Science and Technology. Earthscan, London, pp. 301-315.

4. Calvelo-Pereira, R., Kaal, J., Camps-Arbestain, M., Pardo-Lorenzo, R., Aitkenhead, W., Hedley, M., Macías, F., Hindmarsh, J., Maciá-Agulló, J. A., 2011. Contribution to characterisation of biochar to estimate the labile fraction of carbon. Organic Geochemistry 42, 1331-1342.

5. Bardgett, R., 2005. The Biology of Soil: A community and ecosystem approach. Oxford University Press. Oxford, UK. 
6. Bartoń, K., 2007. Model selection and model averaging based on information criteria (AICc and alike): Package 'MuMIn'. http://cran.rproject.org/web/packages/MuMIn/MuMIn.pdf [accessed on 2 April 2013]

7. Bauhus, J., Meyer, A.C., Brumme, R., 1996. Effect of nitrapyrin and sodium chlorate on nitrification and $\mathrm{N}_{2} \mathrm{O}$ formation in an acid forest soil. Biology and Fertility of Soils $22,318-325$.

8. Belser, L.W., Mays, E.L., 1980. Specific inhibition of nitrite oxidation by chlorate and its use in assessing nitrification in soils and sediments. Applied and Environmental Microbiology 39, 505-510.

9. Biederman, L.A., Harpole, S., 2013. Biochar and its effects on plant productivity and nutrient cycling: a meta-analysis. GCB Bioenergy 5, 202-214.

10. Borchard, N., Prost, K., Kautz, T., Moeller, A., Siemens, J., 2012. Sorption of copper (II) and sulphate to different biochars before and after composting with farmyard manure. European Journal of Soil Science 63, 399-409.

11. Bradford, M.A., Tordoff, G.M., Eggers, T., Jones, T.H., Newington, J.E., 2002. Microbiota, fauna, and mesh size interactions in litter decomposition. Oikos 99, 317-323.

12. Brookes, P.C., Joergensen, R.G., 2006. Microbial biomass measurements by fumigation-extraction. in: Bloem, J., Hopkins, D.W., Benedetti, A. (Eds.), Microbiological Methods for Assessing Soil Quality. CABI Publishing. King's Lynn, UK.

13. Bruun, E.W., Ambus, P., Egsgaard, H., Haugaard-Nielsen, H., 2012. Effects of slow and fast pyrolysis biochar on soil C and $\mathrm{N}$ turnover dynamics. Soil Biology and Biochemistry 46, 73-79. 
14. Burns, L.C., Stevens, R.J., Laughlin, R.J., 1996. Production of nitrite in soil by simultaneous nitrification and denitrification. Soil Biology and Biochemistry 28, 609616.

15. Busscher, W.J., Novak, J.M., Evans, D.E., Watts, D.W., Niandou, M.A.S, Ahmedna, M., 2010. Influence of pecan biochar on physical properties of a norfolk loamy sand. Soil Science 175,10-14.

16. Cayuela, M.L., Sánchez-Monedero, M.A., Roig, A., Hanley, K., Enders, A., Lehmann, J., 2013. Biochar and denitrification in soils: when, how much and why does biochar reduce N2O emissions?. Scientific Reports 3, 1732.

17. Cheng, C.H., Lehmann, J., Engelhard, M., 2008. Natural oxidation of black carbon in soils: changes in molecular form and surface charge along a climosequence. Geochimica et Cosmochimica Acta 72, 1598-1610.

18. Churka Blum, S., Lehmann, J., Solomon, D., Caires, E.F., Alleoni, R.L.F., 2013. Sulfur forms in organic substrates affecting S mineralization in soil. Geoderma 200201, 156-164.

19. Clough, T.J., Condron, L.M., Kammann, C., Müller, C., 2013. A review of biochar and soil nitrogen dynamics. Agronomy 3, 275-293.

20. Cole, L., Staddob, P.L., Sleep, D., Bardgett, R. 2004. Soil animals influence microbial abundance, but not plant-microbial competition for soil organic nitrogen. Functional Ecology 18, 631-640.

21. Cortet, J., Andersen, M.N., Caul, S., Griffiths, B., Joffre, R., Lacroix, B., Sausse, C., Thompson, J., Krogh, P.H., 2006. Decomposition processes under Bt (Bacillus thuringiensis) maize: Results of a multi-site experiment. Soil Biology and Biochemistry 38, 195-199. 
22. Deenik, J.L., McClellan, T., Uehara, G., Antal, N.J., Campbell, S., 2010. Charcoal volatile matter content influences plant growth and soil nitrogen transformations. Soil Science Society of America 74, 1259-1270.

23. DeLuca, T.H., MacKenzie, M.D., Gundale, M.J., 2009. Biochar effects on soil nutrient transformation. in: Lehmann, J., Joseph, S. (Eds.), Biochar for Environmental Management: Science and Technology. Earthscan, London, pp. 251-280.

24. Downie, A., Crosky, A., Munroe, P., 2009. Physical properties of biochar. in: Lehmann, J., Joseph, S. (Eds.), Biochar for environmental management: Science and Technology. Earthscan, London.

25. Ennis, C.J., Evans, A.G., Islam, M., Ralebitso-Senior, K., Senior, E., 2012. Biochar: carbon sequestration, land remediation, and impacts on soil microbiology. Critical Reviews in Environmental Science and Technology 42, 2311-2364.

26. Filzek, P.D.B., Spurgeon, D.J., Broll, G., Svendsen, C., Hankard, P.K., Parekh, N., Stubberud, H.E., Weeks, J.M., 2004. Metal effects on soil invertebrate feeding: measurements using the bait lamina method. Ecotoxicology 13, 807-816.

27. Förster, B., Van Gestel, C.A.M., Koolhaas, J.E., Nentwig, G., Rodrigues, J.M.L., Sousa, J.P., Jones, S.E., Knacker, T., 2004. Ring-testing and field-validation of a terrestrial model ecosystem (TME) - an instrument for testing potentially harmful substances: effects of carbendazim on organic matter breakdown and soil fauna feeding activity. Ecotoxicology 13, 129-141.

28. Gee, G.W., Bauder, J.W., 1986. Particle-size analysis. in: Klute, A. (Ed.), Methods of soil analysis. Part 1: Physical and Mineralogical Methods. 2nd edition. Agronomy Monographs 9. ASA and SSSA, Madison, WI. 
29. Gell, K., van Groenigen, J., Cayuela, M.L., 2011. Residues of bioenergy production chains as soil 17 amendments: Immediate and temporal phytotoxicity. Journal of Hazardous Materials Journal of Hazardous Materials 186, 2017-2025.

30. Gongalsky, K.B., Persson, T., Pokarzhevskii, A.D., 2008. Effects of soil temperature and moisture on the feeding activity of soil animals as determined by the baitlamina test. Applied Soil Ecology 39, 84-90.

31. Güereña, D., Lehmann, J., Hanley, K., Enders, A., Hyland, C., Riha, S., 2013. Nitrogen dynamics following field application of biochar in a temperate North American maize-based production system. Plant and Soil 365, 239-254.

32. Hale, S.E., Alling, V., Martinsen, V., Mulder, J., Breedvelda, G.D., Cornelissen, G., 2013. The sorption and desorption of phosphate- $\mathrm{P}$, ammonium- $\mathrm{N}$ and nitrate- $\mathrm{N}$ in cacao shell and corn cob biochars. Chemosphere 91, 1612-1619.

33. Hale, S.E., Lehmann, J., Rutherford, D., Zimmerman, A.R., Bachmann, R.T., Shitumbanuma, V., O’Toole, A., Sundqvist, K.L, Arp, H.P., Cornelissen, G. 2012. Quantifying the total and bioavailable polycyclic aromatic hydrocarbons and dioxins in biochars. Environmental Science and Technology 46, 2830-2838.

34. Hamel, C., Schellenberg, M.P., Hanson, K., Wang, H., 2007. Evaluation of the 'baitlamina test' to assess soil microfauna feeding activity in mixed grassland. Applied Soil Ecology 36, 199-204.

35. Hartley, W., Uffindell, L., Plumb, A., Rawlinson, H.A., Putwain, P., Dickinson, N.M., 2008. Assessing biological indicators for remediated anthropogenic urban soils. Science of the Total Environment 405, 358-369.

36. Helling, B., Pfeiff, G., Larink, O., 1998. A comparison of feeding activity of collembolan and enchytraeid in laboratory studies using the bait-lamina test. Applied Soil Ecology 7, 207-212. 
37. Hollister, C.C., Bisogni, J.J., Lehmann, J., 2013. Ammonium, nitrate, and phosphate sorption to and solute leaching from biochars prepared from Corn Stover (Zea mays L.) and Oak Wood (Quercus spp.). Journal of Environmental Quality 42, 137-144.

38. Hönemann, L., Zurbrügg, C., Nentwig, W., 2008. Effects of Bt-corn decomposition on the composition of the soil meso- and macrofauna. Applied Soil Ecology 40, 203-209.

39. ISO (International Organization for Standardization), 1999. Soil quality - Inhibition of reproduction of Collembola (Folsomia candida) by soil pollutants. ISO Guideline 11267, International Standardization Organization, Geneva, Switzerland.

40. ISO (International Organization for Standardization)., 2004. Soil quality - Effects of pollutants on Enchytraeidae (Enchytraeus sp.) - Determination of effects on reproduction and survival. ISO Guideline 16387, International Standardization organization, Geneva, Switzerland.

41. Jeffery, S., Verheijen, F., van der Velde, M., Bastos, A.C. 2011. A quantitative review of the effects of biochar application to soils on crop productivity using metaanalysis. Agriculture, Ecosystems and Environments 144, 175-187.

42. Jin, H., 2010. Characterization of microbial life colonizing biochar and biocharamended soils. PhD dissertation, Cornell University, Ithaca, NY, USA.

43. Johansen, J.M., Jakobsen, J.G., Frandsen, F.J., Glarborg, P., 2011. Release of K, $\mathrm{Cl}$, and S during pyrolysis and combustion of high-chlorine biomass. Energy Fuels 25, 4961-4971.

44. Keith, A., Singh, B., Singh, B.P., 2011. Interactive priming of biochar and labile organic matter mineralization in a smectite-rich soil. Environmental Science and Technology 45, 9611-9618. 
45. Knacker, T., Förster, B., Römbke, J., Frampton, G., 2003. Methods for assessing the effects of pesticides on organic matter breakdown. Soil Biology and Biochemistry 35, 1269-1287.

46. Kookana, R.S., Sarmah, A.K., Van Zwieten, L., Krull, E., Singh, B., 2011. Biochar application to soil: Agronomic and environmental benefits and unintended consequences. Advances in Agronomy 112, 103-143.

47. Kratz, W., 1998. The bail-lamina test. Environmental Science and Pollution Research 5, 94-96.

48. Laird, D., Fleming, P., Wang, B., Horton, R., Karlen, D., 2010. Biochar impact on nutrient leaching from Midwester agricultural soil. Geoderma 158, 436-442.

49. Lavelle, P., Decaëns, T., Aubert, M., Barot, S., Blouin, M., Bureau, F., Margerie, P., Mora, P., Rossi, J.-P., 2006. Soil invertebrates and ecosystem services. European Journal of Soil Biology 42, S3-S15.

50. Lehmann, J., Czimczik, C., Laird, C., Sohi, S., 2009. Stability of biochar in soil. in: Lehmann, J., Josep, S., (Eds.), Biochar for environmental management: Science and Technology. Earthscan, London.

51. Lehmann, J., da Silva, Jr. J.P., Steiner, C., Nehls, T., Zech, W., Glaser, B., 2003. Nutrient availability and leaching in an archaeological Anthrosol and a Ferralsol of the Central Amazon basin: fertilizer, manure and charcoal amendments. Plant and Soil 249, 343-357.

52. Lehmann, J., Joseph, S., 2009. Biochar for environmental management: An introduction. in: Lehmann, J., Joseph, S., (Eds.), Biochar for environmental management: Science and Technology. Earthscan, London. 
53. Lehmann, J., Rillig, M.C., Thies, J., Masiello, C.A., Hockaday, W.C., Crowley, D., 2011. Biochar effects on soil biota - A review. Soil Biology and Biochemistry 43, 1812-1836.

54. Liang, B., Lehmann, J., Sohi, S.P., Thies, J.E., O'Neill, B., Trujillo, L., Gaunt, J., Solomon, D., Grossman, J., Neves, E.G., Luizão, F.J., 2010. Black carbon affects the cycling of non-black carbon in soil. Organic Geochemistry 41, 206-213.

55. Liang, B., Lehmann, J., Solomon, D., Kinyangi, J., Grossman, J., O'Neill, B., Skjemstad, J.O., Thies, J., Luizão, F.J., Petersen, J., Neves, E.G., 2006. Black carbon increases cation exchange capacity in soil. Soil Science Society of America Journal $70,1719-1730$.

56. Liesch, A.M., Weyers, S.L., Gaskin, J.W., Das, K.C., 2010. Impact of two different biochars on earthworm growth and survival. Annals of Environmental Science 4, 19.

57. Liu, X.-H., Han, F.-P., Zhang, X.-C., 2012. Effect of biochar on soil aggregates in the loess plateau: results from incubation experiments. International Journal of Agriculture and Biology 14, 975-979.

58. Major, J., Rondon, M., Molina, D., Riha, S.J., Lehmann, J., 2010. Maize yield and nutrition during 4 years after biochar application to a Colombian savanna oxisol. Plant and Soil 333, 117-128.

59. Major, J., Rondon, M., Molina, D., Riha, S.J., Lehmann, J., 2012. Nutrient leaching in a Colombian savanna Oxisol amended with biochar. Journal of Environmental Quality 41, 1076-1086.

60. Mann, L., Tolbert, V., Cushman, J., 2002. Potential environmental effects of corn (Zea mays L.) stover removal with emphasis on soil organic matter and erosion. Agriculture, Ecosystems and Environment 89, 149-166. 
61. McCormack, S.A., Ostle, N., Bardgett, R.D., Hopkins, D.W., Vanbergen, A.J., 2013. Biochar in bioenergy cropping systems: impacts on soil faunal communities and linked ecosystem processes. GCB Bioenergy 5, 81-95.

62. McGrath, S.P., Zhao, F.J., Withers, P.J.A., 1996. Development of sulphur deficiency in crops and its treatment. Proceedings of the Fertiliser Society 379, pp.87-92, Peterborough, UK.

63. Murphy, J., Riley, J.P., 1962. A modified single solution method for the determination of phosphate in natural waters. Analytica Chimica Acta. 27, 31-36.

64. Nelson, D.W., Sommers, L.E., 1982. Total carbon, organic carbon, and organic matter. in: Page, A.L., Miller, R.H., Keeney, D.R., (Eds.), Methods of soil analysis. Part 2: Chemical and Microbiological Properties. 2nd ed. Agronomy Monographs 9. ASA and SSSA, Madison, WI, USA.

65. Nielsen, U.N., Ayres, E., Wall, D.H., Bardgett, R.D., 2011. Soil biodiversity and carbon cycling: A review and synthesis of studies examining diversity-function relationships. European Journal of Soil Science 21, 105-116.

66. Öberg, G., 2002. The natural chlorine cycle - fitting the scattered pieces. Applied Microbiology and Biotechnology 58, 565-581.

67. OECD (Organisation for Economic Co-operation and Development)., 2000a. Guideline for the Testing of Chemicals. Soil Microorganisms: Nitrogen Transformation Test. OECD Guideline 216, Geneva, Switzerland.

68. OECD (Organisation for Economic Co-operation and Development)., 2000b. Guideline for the Testing of Chemicals. Soil Microorganisms: Carbon Transformation Test. OECD Guideline 217, Geneva, Switzerland.

69. Ogawa, M., Okimori, Y., 2010. Pioneering works in biochar research in Japan. Australian Journal of Soil Research 48, 489-500. 
70. Pell, M., Stenström, J., Granhall, U., 2006. Soil Respiration. in: Bloem, J., Hopkins, D.W., Benedetti, A., (Eds.), Microbiological Methods for Assessing Soil Quality. CABI Publishing. King's Lynn, UK

71. Pietikäinen, J., Kiikkilä, O., Fritze, H., 2000. Charcoal as a habitat for microbes and its effect on the microbial community of the underlying humus. Oikos 89, 231-242.

72. R Development Core Team., 2012. R: A language and environment for statistical computing. R Foundation for Statistical Computing, Vienna, Austria. ISBN 3900051-07-0, URL http://www.R-project.org [accessed on 22 October 2013].

73. Rahim, M.U., Gao, X., Garcia-Perez, M., Li, Y., Wu, H., 2013. Release of chlorine during mallee bark pyrolysis. Energy and Fuels 27, 310-317.

74. Reinecke, A.J., Albertus, R.M.C., Reinecke, S.A., Larink, O., 2008. The effects of organic and conventional management practices on feeding activity of soil organisms in vineyards. African Zoology 43, 66-74.

75. Schimel, J., Balser, T.C., Wallenstein, M., 2007. Microbial stress-response physiology ans its implications for ecosystem function. Ecology 88, 1386-1394.

76. Sohi, S.P., Krull, E., Lopez-Capel, E., Bol, R., 2010. A Review of biochar and its use and function in soil. Advances in Agronomy 105, 47-82.

77. Spokas, K.A., Cantrell, K.B., Novak, J.M., Archer, D.W., Ippolito, J.A., Collins, H.P., Boateng, A.A., Lima, I., Lambh, M.C., Aloon, A.J., Lentzd, R.D., Nichols, K.A., 2012. Biochar: A synthesis of its agronomic impact beyond carbon sequestration. Journal of Environmental Quality 41, 973-989.

78. Spokas, K.A., 2010. Review of the stability of biochar in soils: predictability of O:C molar ratios. Carbon Management 1, 289-303. 
79. Steiner, C., Glaser, B., Teixeira, W.G., Lehmann, J., Blum, W.E.H., Zech, W., 2008. Nitrogen retention and plant uptake on a highly weathered central Amazonian Ferralsol amended with compost and charcoal. Journal of Plant Nutrition and Soil Science 171: 893-899.

80. Taghizadeh-Toosi, A., Clough, T.J., Sherlock, R.R., Condron, L.M., 2012. Biochar adsorbed ammonia is bioavailable. Plant and Soil 350, 57-69.

81. Tarkalson, D.D., Kachman, S.D., Knops, J.M.N., Thies, J.E., Wortmann, C.S., 2008. Decomposition of Bt and non-Bt corn hybrid residues in the field. Nutrient Cycling in Agroecosystems 80, 211-222.

82. Thies, J., Rillig, M.C., 2009. Characteristics of biochar: Biological properties. in: Lehmann, J., Josep, S., (Eds.), Biochar for environmental management: Science and Technology. Earthscan, London.

83. Uchimiya, M., Lima, I.M., Klasson, K.T., Wartelle, L.H., 2010. Contaminant immobilization and nutrient release by biochar soil amendment: Roles of natural organic matter. Chemosphere 80, 935-940.

84. Van Gestel, C.A.M., Kruidenier, M., Berg, M.P., 2003. Suitability of wheat straw decomposition, cotton strip degradation and bait-lamina feeding tests to determine soil invertebrate activity. Biology and Fertility of Soils 37, 115-123.

85. Verheijen, F., Jeffery, S., Bastos, A.C., van der Velde, M., Diafas, F., 2010. Biochar application to soils. A critical scientific review of effects on soil properties, processes, and functions. EUR 24099 EN. Office for the Official Publications of the European Communities, Louxembourg.

86. Von Törne, E., 1990. Assessing feeding activities of soil-living animals. I. Baitlamina tests. Pedobiologia 34, 89-101. 
87. Wardle, D.A., Ghani, A., 1995. A critique of the microbial metabolic quotient $\left(\mathrm{qCO}_{2}\right)$ as a bioindicator of disturbance and ecosystem development. Soil Biology and Biochemistry 27: 1601-1610.

88. Wardle, D.A., Yeates, G.W., Nicholson, K.S., Bonner, K.I., Watson, R.N., 1999. Response of soil microbial biomass dynamics, activity and plant litter decomposition to agricultural intensification over a seven-year period. Soil Biology and Biochemistry 31, 1707-1720.

89. Warnock, D.D., Lehmann, J., Kuyper, T.W., Rillig, M.C., 2007. Mycorrhizal responses to biochar in soil - Concepts and mechanisms. Plant and Soil 300: 9-20.

90. Weyers, S.L., Spokas, K.A., 2011. Impact of biochar on earthworm populations: a review. Applied and Environmental Soil Science 2011, Article ID 541592, 1-12.

91. Woolf, D., Amonette, J.E., Street-Perrott, F.A., Lehmann, J., Joseph, S., 2010. Sustainable biochar to mitigate global climate change. Nature Communications 1 , 56.

92. Woolf, D., Lehmann, J., 2012. Modelling the long-term response to positive and negative priming of soil organic carbon by black carbon. Biogeochemistry $111,83-$ 95.

93. Zimmerman, A., Gao, B., Ahn, M.-Y., 2011. Positive and negative carbon mineralization priming effects among a variety of biochar amended soils. Soil Biology and Biochemistry 43, 1169-1179. 
Table 1. Summer microbial activity values, mean annual feeding rates, and litter decomposition rates after corn biochar additions to a temperate soil. BAS corresponds to the basal soil respiration expressed as $\mu \mathrm{g} \mathrm{C}-\mathrm{CO}_{2} \mathrm{~g}^{-1} \mathrm{~h}^{-1}$, MCB corresponds to the microbial biomass expressed as $\mu \mathrm{g} C \mathrm{~g}^{-1}$, while the remainder values are expressed as percent; $\mathrm{CMC}$ corresponds to the carbon mineralization coefficient, expressed as $\mu \mathrm{g} \mathrm{C}-\mathrm{CO}_{2} \mathrm{~g} \mathrm{SOC}^{-1}$; $\mathrm{qCO}_{2} \mathrm{Corresponds}$ to the BAS to MCB ratio.

\begin{tabular}{|c|c|c|c|c|c|c|c|c|c|}
\hline Biochar $\left(\mathrm{t} \mathrm{ha}^{-1}\right)$ & Plot & BAS & MCB & CMC & $\mathrm{qCO}_{2}$ & $\begin{array}{c}\text { Fauna feeding rate } \\
\text { (quantitative) }\end{array}$ & $\begin{array}{c}\text { Fauna feeding rate } \\
\text { (qualitative) }\end{array}$ & $\begin{array}{l}\text { Litter decomposition } \\
\text { (2-mm mesh bags) }\end{array}$ & $\begin{array}{l}\text { Litter decomposition } \\
\text { (0.16-mm mesh bags) }\end{array}$ \\
\hline \multirow[t]{3}{*}{0} & 4 & 0.72 & 528.2 & 0.042 & 0.001 & 0.44 & 0.56 & 0.55 & 0.55 \\
\hline & 8 & 0.61 & 243.3 & 0.037 & 0.003 & 0.27 & 0.39 & 0.50 & 0.54 \\
\hline & 16 & 0.70 & 272.9 & 0.039 & 0.003 & 0.44 & 0.54 & 0.59 & 0.58 \\
\hline \multirow[t]{3}{*}{3 (1 per year) } & 11 & 0.52 & 287.9 & 0.020 & 0.002 & 0.43 & 0.57 & 0.55 & 0.57 \\
\hline & 18 & 0.83 & 329.0 & 0.046 & 0.003 & 0.36 & 0.43 & 0.52 & 0.54 \\
\hline & 31 & 0.67 & 558.1 & 0.033 & 0.001 & 0.32 & 0.39 & 0.56 & 0.56 \\
\hline \multirow[t]{3}{*}{3} & 6 & 0.78 & 380.9 & 0.031 & 0.002 & 0.44 & 0.56 & 0.52 & 0.51 \\
\hline & 10 & 0.55 & 382.8 & 0.029 & 0.001 & 0.40 & 0.50 & 0.57 & 0.54 \\
\hline & 35 & 0.99 & 318.9 & 0.039 & 0.003 & 0.27 & 0.38 & 0.51 & 0.55 \\
\hline \multirow[t]{3}{*}{12} & 1 & 0.72 & 201.6 & 0.041 & 0.004 & 0.43 & 0.55 & 0.46 & 0.48 \\
\hline & 13 & 0.63 & 210.4 & 0.024 & 0.003 & 0.39 & 0.50 & 0.51 & 0.57 \\
\hline & 29 & 0.67 & 430.28 & 0.022 & 0.002 & 0.41 & 0.53 & 0.57 & 0.60 \\
\hline \multirow[t]{3}{*}{30} & 14 & 0.68 & 350.5 & 0.039 & 0.002 & 0.52 & 0.66 & 0.53 & 0.57 \\
\hline & 27 & 0.65 & 977.0 & 0.026 & 0.001 & 0.43 & 0.53 & 0.57 & 0.57 \\
\hline & 36 & 1.06 & 864.1 & 0.049 & 0.001 & 0.39 & 0.50 & 0.56 & 0.60 \\
\hline
\end{tabular}


Figure 1. Soil moisture in the summer sampling, and $\mathrm{pH}$, electrical conductivity, and soil organic carbon in both summer (black bars) and fall (white bars) for different biochar application rates $\left(0,3,12\right.$ and $30 \mathrm{t} \mathrm{ha}^{-1}$ added once four years prior to the study, and $1 \mathrm{t} \mathrm{ha}^{-1}$ added annually). Error bars correspond to the standard deviation $(p<0.05, n=3)$, while asterisks indicate significant differences compared to the respective control plots $\left(0 \mathrm{t} \mathrm{ha}^{-1}\right)$.
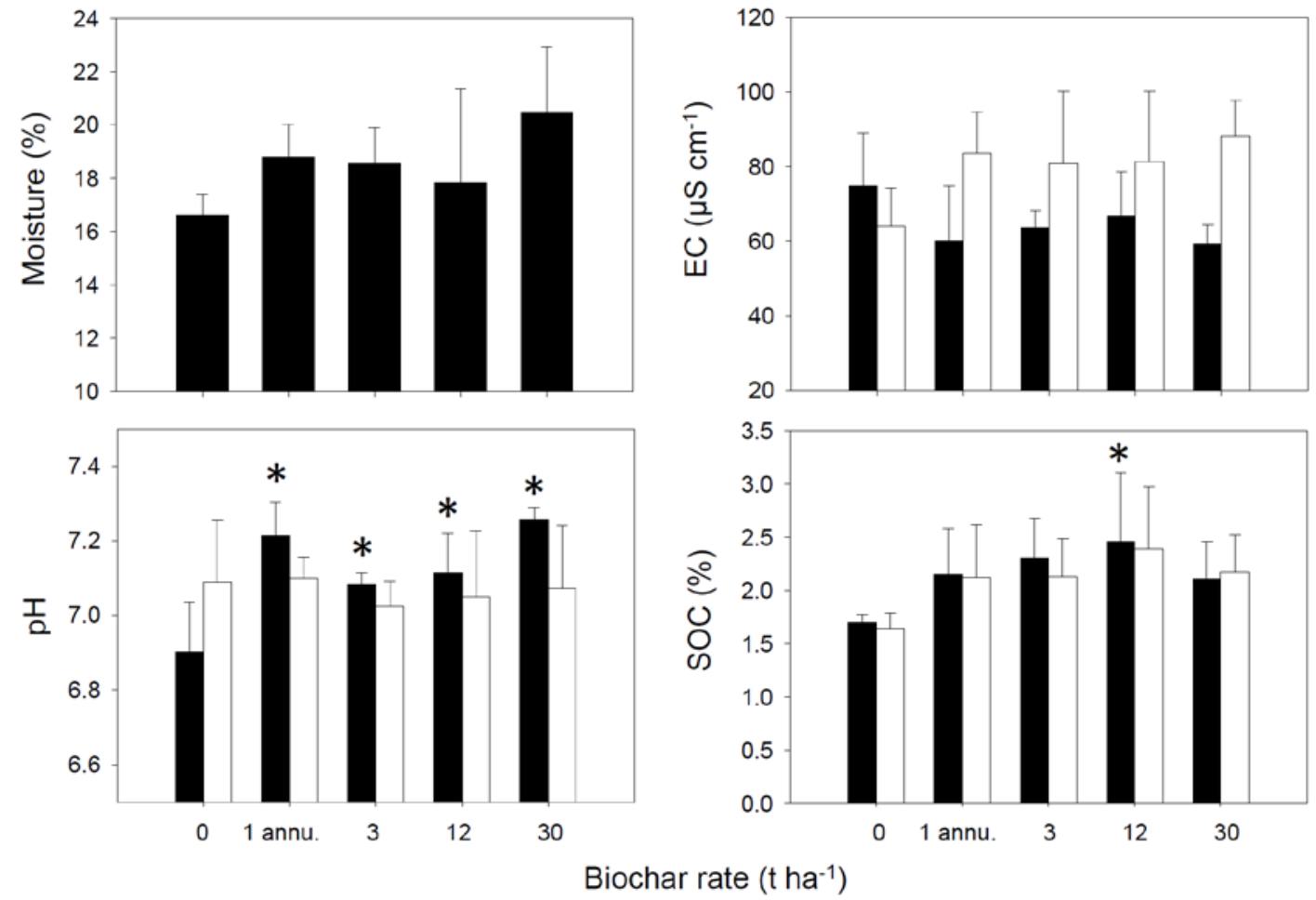
Figure 2. Microbial dynamics as affected by different biochar application rates. Error bars correspond to the standard deviation, while asterisks indicate significant differences compared to the respective control plots $\left(0 \mathrm{t} \mathrm{ha}^{-1}\right)(\mathrm{p}<0.05, \mathrm{n}=3)$; $M C B=$ microbial biomass, $B A S=$ basal respiration, $C M C=$ carbon mineralization coefficient; $\mathrm{qCO}_{2}=$ metabolic quotient.
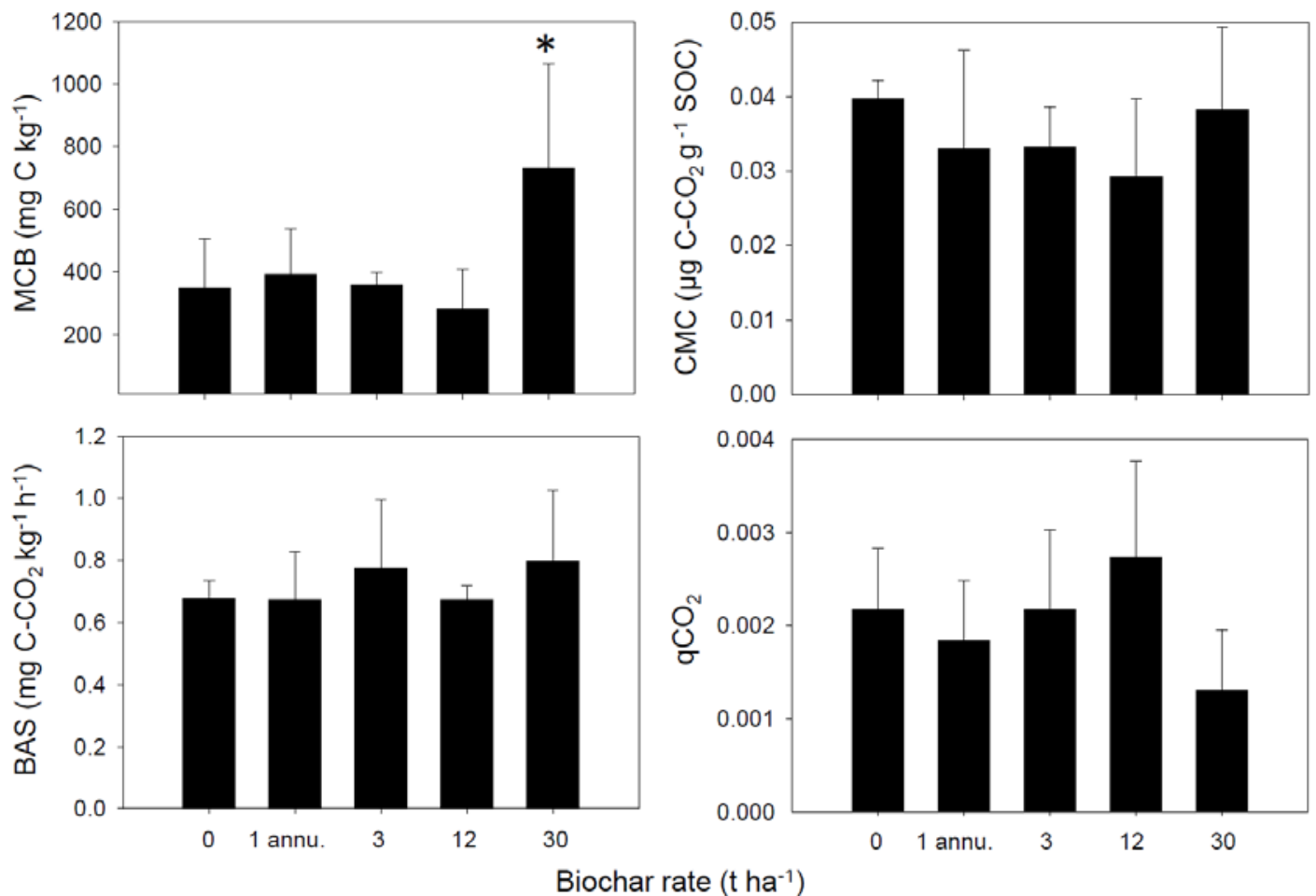
Figure 3. Fauna feeding activity, expressed as a rate, for the different biochar application rates in summer (black bars) and fall (white bars) for different soil depths. Error bars correspond to the standard deviation. No significant differences of the biochar-added plots compared to the respective controls $\left(0 \mathrm{t} \mathrm{ha}^{-1}\right)$ were observed $(p<0.05, n=3)$.
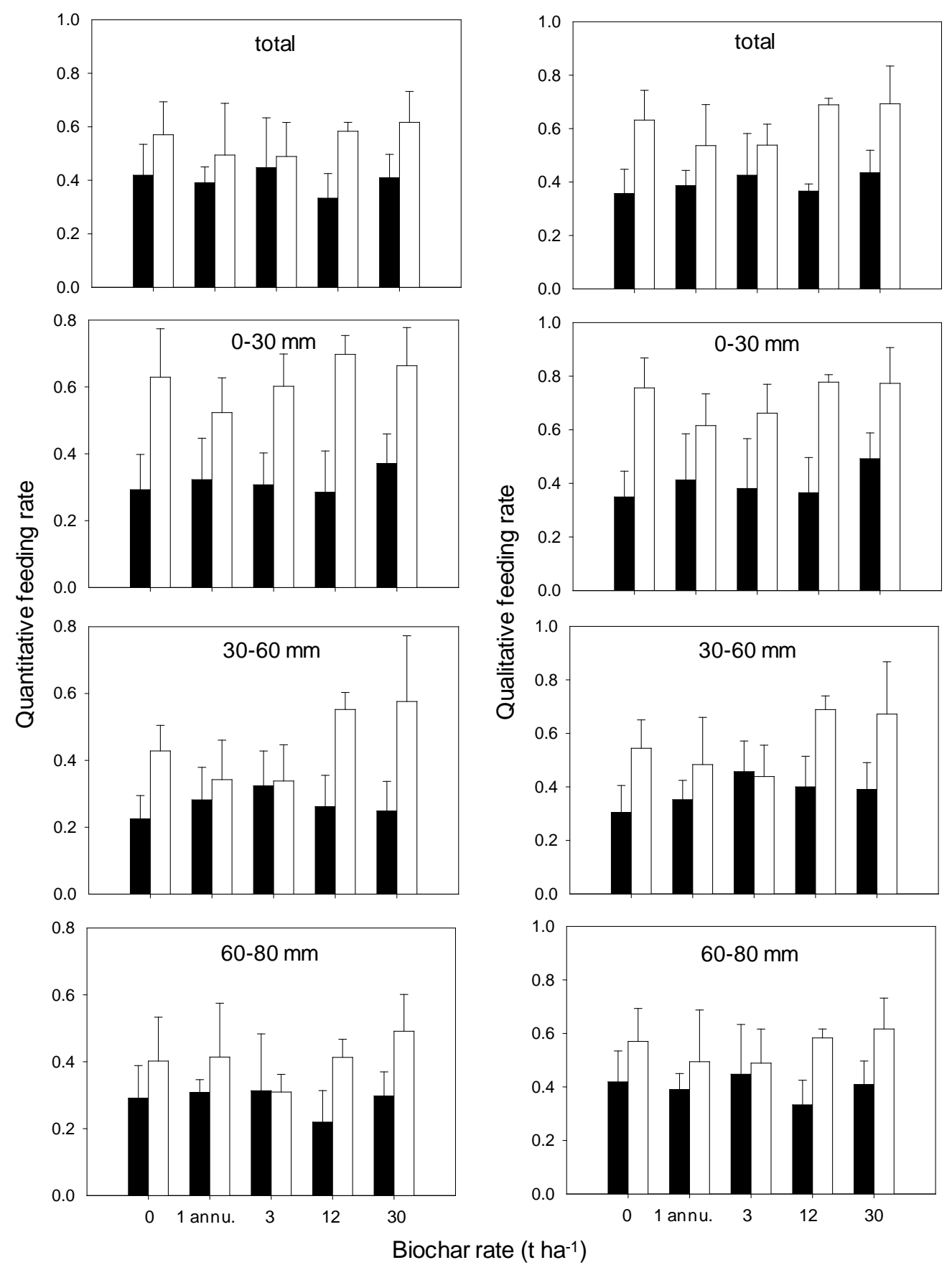
Figure 4. Litter decomposition rates for different biochar application rates as affected by microorganisms+microfauna+mesofauna (2-mmmesh litterbags) and microorganisms+microfauna (0.16-mmmesh litterbags). Error bars correspond to the standard deviation. No significant differences of the biochar-added plots compared to controls $\left(0 \mathrm{t} \mathrm{ha}^{-1}\right)$ were observed $(p<0.05, n=3)$.

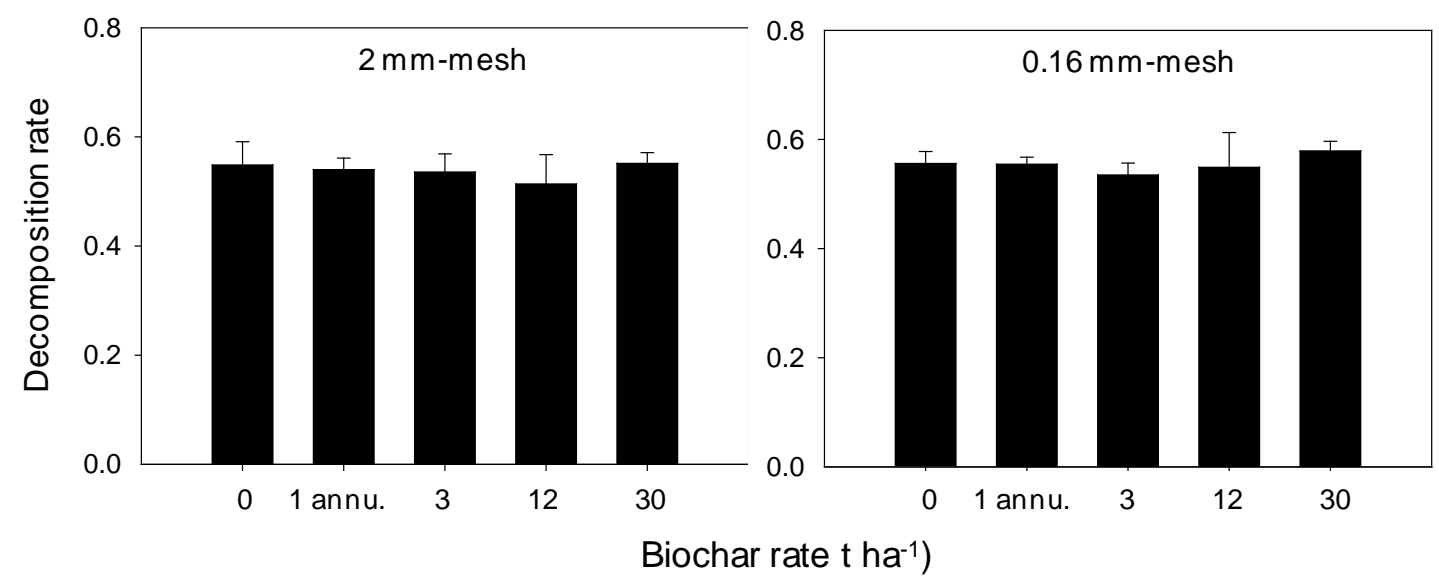


Figure 5. Mineralization and release rates of several ions during a 28-d incubation period, after the addition of corn litter to soil samples collected from plots with different biochar application rates. Rates are expressed as $\mathrm{mg} / \mathrm{kg}$. day, and negative values indicate a decrease in the ion content along the incubation. Significant differences in the rates of the biochar-added plots compared to controls $\left(0 \mathrm{t} \mathrm{ha}^{-1}\right)$ are indicated with an asterisk $(p<0.05, n=3)$.
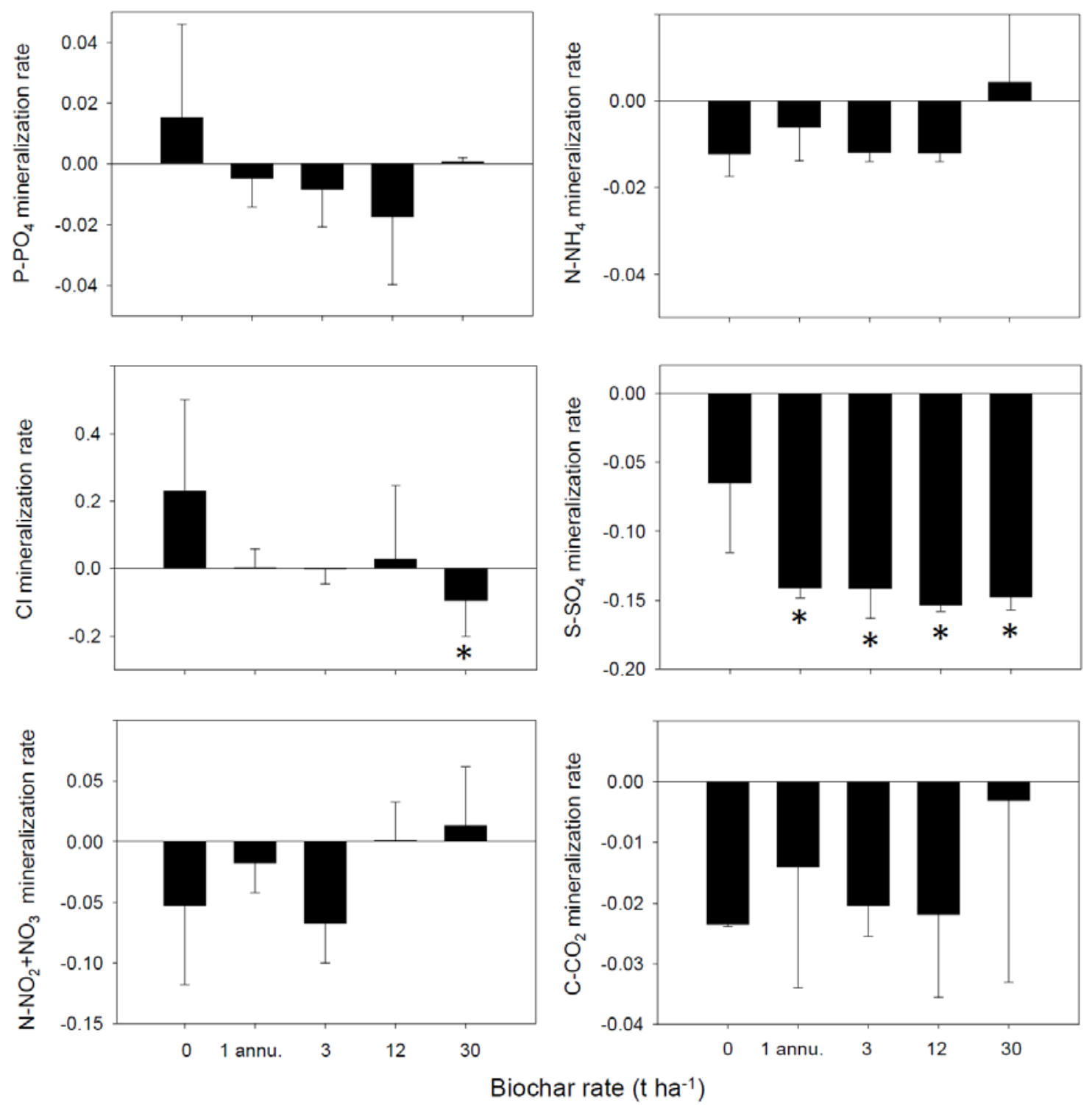


\section{Supplementary Online Material}

\section{Medium-term effects of corn biochar addition on soil biota activities and functions in a temperate soil cropped to corn}

Xavier Domene ${ }^{1,2,3, *}$, Stefania Mattana ${ }^{1}$, Kelly Hanley ${ }^{3}$, Akio Enders ${ }^{3}$ Johannes Lehmann $^{3}$

${ }^{1}$ CREAF, Cerdanyola del Vallès 08193, Spain

${ }^{2}$ Univ Autònoma Barcelona, Cerdanyola del Vallès 08193, Spain

${ }^{3}$ Department of Crop and Soil Sciences, Cornell University, Ithaca, New York 14853, United States

*Corresponding author.CREAF.Facultat de Ciències i Biociències.Autonomous University of Barcelona.CerdanyoladelVallès08193, Barcelona, Spain, Phone: +34935 811 987, Fax: +34935 814151

E-mail addresses: x.domene@creaf.uab.es (Xavier Domene), s.mattana@creaf.uab.es (Stefania Mattana), klh54@cornell.edu (Kelly Hanley), ae55@cornell.edu (Akio Enders), CL273@cornell.edu (Johannes Lehmann). 
Table S1. Mean annual values for the physicochemical measurements in the different plots and treatments, all expressed on a dry weight basis.

\begin{tabular}{|c|c|c|c|c|c|c|c|c|c|c|c|c|c|c|}
\hline $\begin{array}{c}\text { Biochar } \\
\text { t/ha }\end{array}$ & Plot & $\begin{array}{c}\text { Sand } \\
\%\end{array}$ & $\begin{array}{c}\text { Silt } \\
\%\end{array}$ & $\begin{array}{c}\text { Clay } \\
\%\end{array}$ & $\begin{array}{c}\text { Moisture } \\
\%\end{array}$ & pH & $\begin{array}{c}\text { EC } \\
\mu \mathrm{Scm}^{-1}\end{array}$ & $\begin{array}{c}\text { SOC } \\
\%\end{array}$ & $\begin{array}{l}\text { P-PO4 } \\
\mathrm{mg} \mathrm{kg}^{-1}\end{array}$ & $\begin{array}{c}\mathbf{C l} \\
\mathrm{mg} \mathrm{kg}^{-1}\end{array}$ & $\begin{array}{l}\text { N-NO2 } \\
\text { mg kg }^{-1}\end{array}$ & $\begin{array}{l}\text { N-NO3 } \\
\mathrm{mg} \mathrm{kg}^{-1}\end{array}$ & $\begin{array}{l}\text { N-NH4 } \\
\text { mg kg-1 }^{-1}\end{array}$ & $\begin{array}{l}\mathrm{S}-\mathrm{SO} 4 \\
\mathrm{mg} \mathrm{kg}^{-1}\end{array}$ \\
\hline \multirow{3}{*}{0} & 4 & 61.5 & 20.3 & 18.2 & 16.3 & 6.9 & 73.1 & 1.7 & 1.5 & 13.7 & 0.7 & 22.9 & 8.3 & 27.5 \\
\hline & 8 & 62.2 & 20.2 & 17.6 & 16.1 & 6.9 & 64.5 & 1.6 & 1.2 & 16.3 & 1.2 & 19.5 & 9.7 & 43.0 \\
\hline & 16 & 56.1 & 19.3 & 24.6 & 17.5 & 7.1 & 69.9 & 1.7 & 0.8 & 18.3 & 0.9 & 7.9 & 1.4 & 80.2 \\
\hline \multirow[b]{2}{*}{3 (1 per year) } & 11 & 62.7 & 19.4 & 17.9 & 17.4 & 7.1 & 72.4 & 1.8 & 1.9 & 22.3 & 0.9 & 9.1 & 9.3 & 138.9 \\
\hline & 18 & 56.9 & 23.9 & 19.2 & 19.2 & 7.2 & 77.1 & 2.2 & 1.4 & 40.2 & 0.6 & 16.4 & 2.0 & 59.3 \\
\hline \multirow[t]{2}{*}{3} & 10 & 62.8 & 21.1 & 16.1 & 19.0 & 7.0 & 69.8 & 2.0 & 1.7 & 10.7 & 0.9 & 12.6 & 8.9 & 75.7 \\
\hline & 35 & 56.3 & 26.0 & 17.7 & 19.6 & 7.1 & 79.1 & 2.5 & 2.5 & 19.2 & 1.1 & 7.8 & 0.2 & 137.4 \\
\hline \multirow{3}{*}{12} & 1 & 60.0 & 22.0 & 18 & 15.0 & 7.1 & 66.2 & 1.7 & 4.3 & 29.2 & 2.5 & 7.1 & 13.1 & 130.2 \\
\hline & 13 & 63.4 & 20.9 & 15.7 & 16.8 & 7.1 & 71.3 & 2.3 & 3.0 & 12.8 & 0.9 & 13.9 & 9.5 & 95.5 \\
\hline & 29 & 58.3 & 18.7 & 22.9 & 21.8 & 7.1 & 90.4 & 2.5 & 1.3 & 22.4 & 0.6 & 15.3 & 0.4 & 115.4 \\
\hline
\end{tabular}


Table S2. Generalized linear models with best goodness of fit (lowest AICc) of microbial measurements using explanatory variables from the summer sampling, when those microbial measurements were carried out. All the parameters are significant in itself in the model except those indicated as (ns).

\begin{tabular}{|c|c|c|c|c|c|c|c|c|c|}
\hline \multirow[t]{2}{*}{$\begin{array}{l}\text { Response } \\
\text { variable }\end{array}$} & \multicolumn{9}{|c|}{ Explanatory variable coefficients } \\
\hline & intercept & moisture & sand & loam & clay & SOC.summer & $\mathrm{NO}_{3}$.summer & AICc & $r^{2}$ \\
\hline $\log M C B$ & 1.315 & 0.068 & & & & & & -10.6 & 0.56 \\
\hline BAS & -229.2 & & 2.287 & 2.317 & 2.316 & & & -13.9 & 0.62 \\
\hline CMC & 0.440 & & & & & & -0.006 (ns) & -19.5 & 0.14 \\
\hline qCO2 & 0.017 & 0.0004 & -0.0001 & & & $0.0008(\mathrm{~ns})$ & & -178.8 & 0.68 \\
\hline
\end{tabular}


Table S3. Pairwise Pearson correlation coefficients of the biological responses assessed. Fauna feeding rates correspond to the mean of the summer and fall values. Significant relationships are indicated by coefficients highlighted in bold and asterisks indicating the significance $(*=\mathrm{p} \leq 0.05, * *=\mathrm{p} \leq 0.01) ; \mathrm{n}=15$.

\begin{tabular}{|c|c|c|c|c|c|c|c|c|c|c|c|c|c|c|c|}
\hline & Biochar rate & $\begin{array}{c}\text { Fauna } \\
\text { feedingrate } \\
\text { (quantitative) }\end{array}$ & $\begin{array}{c}\text { Fauna } \\
\text { feedingrate } \\
\text { (qualitative) }\end{array}$ & $\begin{array}{c}\text { Decomposition } \\
\text { (2mm-mesh) }\end{array}$ & $\begin{array}{l}\text { Decomposition } \\
\text { (0.1mm-mesh) }\end{array}$ & BAS & CMC & logMCB & $\mathrm{qCO2}$ & $\begin{array}{c}\text { PO4 } \\
\text { mineralization }\end{array}$ & $\begin{array}{c}\mathrm{Cl} \\
\text { mineralization }\end{array}$ & $\begin{array}{c}\mathrm{NO2+NO3} \\
\text { mineralization }\end{array}$ & $\begin{array}{c}\text { SO4 } \\
\text { mineralization }\end{array}$ & $\begin{array}{c}\mathrm{NH4} \\
\text { mineralization }\end{array}$ & $\begin{array}{c}\mathrm{CO} 2 \\
\text { mineralization }\end{array}$ \\
\hline Biochar rate & 1.00 & & & & & & & & & & & & & & \\
\hline $\begin{array}{l}\text { Fauna feeding } \\
\text { (quantitative) }\end{array}$ & 0.42 & 1.00 & & & & & & & & & & & & & \\
\hline $\begin{array}{l}\text { Fauna feeding } \\
\text { (qualitative) }\end{array}$ & 0.43 & $0.97 * *$ & 1.00 & & & & & & & & & & & & \\
\hline $\begin{array}{l}\text { Decomposition } \\
\text { (2mm-mesh) }\end{array}$ & 0.06 & 0.23 & 0.17 & 1.00 & & & & & & & & & & & \\
\hline $\begin{array}{l}\text { Decomposition } \\
\text { (0.1mm-mesh) }\end{array}$ & 0.36 & 0.03 & 0.05 & $0.69 * *$ & 1.00 & & & & & & & & & & \\
\hline BAS & 0.23 & -0.28 & -0.27 & -0.15 & 0.09 & 1.00 & & & & & & & & & \\
\hline CMC & 0.06 & -0.14 & -0.18 & -0.23 & -0.19 & $0.69 * *$ & 1.00 & & & & & & & & \\
\hline $\log M C B$ & 0.50 & 0.07 & 0.03 & $0.59 *$ & 0.44 & 0.30 & 0.09 & 1.00 & & & & & & & \\
\hline $\mathrm{qCO} 2$ & -0.27 & -0.17 & -0.15 & $-0.71^{* *}$ & -0.42 & 0.06 & 0.16 & $-0.84^{* *}$ & 1.00 & & & & & & \\
\hline $\mathrm{PO}_{4}$ mineralization & -0.08 & -0.17 & -0.13 & -0.27 & -0.24 & -0.19 & 0.22 & -0.16 & 0.10 & 1.00 & & & & & \\
\hline Cl mineralization & -0.43 & 0.01 & 0.00 & -0.03 & -0.43 & -0.01 & 0.36 & 0.03 & -0.04 & 0.06 & 1.00 & & & & \\
\hline $\mathrm{NO}_{2}+\mathrm{NO}_{3}$ mineralization & $0.52^{*}$ & 0.23 & 0.16 & -0.09 & 0.09 & -0.07 & -0.16 & 0.05 & 0.25 & -0.14 & -0.36 & 1.00 & & & \\
\hline $\mathrm{SO}_{4}$ mineralization & -0.42 & 0.16 & 0.16 & 0.31 & -0.06 & -0.12 & 0.24 & 0.08 & -0.19 & 0.24 & $0.77^{* *}$ & -0.37 & 1.00 & & \\
\hline $\mathrm{NH}_{4}$ mineralization & 0.51 & 0.13 & 0.04 & 0.35 & 0.21 & -0.12 & -0.21 & $0.72^{* *}$ & $-0.54^{*}$ & -0.09 & -0.05 & 0.48 & -0.06 & 1.00 & \\
\hline $\mathrm{CO}_{2}$ mineralization & 0.38 & -0.22 & -0.23 & 0.15 & 0.18 & $0.56^{*}$ & 0.39 & $0.60 *$ & -0.39 & -0.10 & 0.02 & 0.18 & -0.15 & 0.22 & 1.00 \\
\hline
\end{tabular}


Table S4. Generalized linear models for fauna feeding rates, for the total values and those at different depths at the two sampling times (summer and fall), expressed as rate. All the parameters are significant in itself in the model except those indicated as (n.s.).Unacceptable models (with no significant parameters in itself included) are indicated as n.a.

\begin{tabular}{|c|c|c|c|c|c|c|c|c|c|c|c|c|c|c|c|}
\hline \multirow[t]{2}{*}{ Sampling } & \multirow[t]{2}{*}{ Response variable } & \multirow{2}{*}{$\begin{array}{c}\text { Depth } \\
\text { (mm) }\end{array}$} & \multicolumn{13}{|c|}{ Explanatory variable coefficients } \\
\hline & & & intercept & biochar & $\log M C B$ & sand & loam & clay & SOC & PO4 & NO2 & NO3 & $\mathrm{Cl}$ & AICc & $r^{2}$ \\
\hline \multirow{8}{*}{ Summer } & \multirow{4}{*}{ Qualitativefeedingrate } & total & -142.98 & & \multirow{4}{*}{0.322} & 1.435 & 1.421 & 1.444 & & & & & & -40.8 & 0.71 \\
\hline & & $0-30$ & -200.77 & & & 2.010 & 2.036 & 1.996 & & & & & & -21.7 & 0.55 \\
\hline & & $30-60$ & -0.55 & & & & & & 0.127 & -0.702 & & & & -22.3 & 0.54 \\
\hline & & $60-80$ & -176.93 & & & 1.776 & 1.757 & 1.782 & & & & & & -31.4 & 0.77 \\
\hline & \multirow{4}{*}{ Quantitativefeedingrate } & total & -115.64 & & & 1.159 & 1.152 & 1.168 & & & & & & -34.3 & 0.55 \\
\hline & & $0-30$ & -156.11 & & & 1.561 & 1.558 & 1.584 & & & & & & -22.8 & 0.52 \\
\hline & & $30-60$ & 0.412 & & & & & & & & $\begin{array}{c}- \\
0.0841\end{array}$ & & & -29.5 & 0.28 \\
\hline & & $60-80$ & -137.47 & & & 1.380 & 1.365 & 1.384 & & & & & & 25.5 & 0.58 \\
\hline \multirow{8}{*}{ Fall } & \multirow{4}{*}{ Qualitativefeedingrate } & total & 1.06 & 0.004(n.s.) & & & -0.023 & & & & & & & -21.8 & 0.53 \\
\hline & & $0-30$ & 1.281 & 0.003(n.s.) & & & -0.028 & & & & & & & -33.4 & 0.69 \\
\hline & & $30-60$ & 1.076 & & & & -0.034 & & & & & & 0.005 & -19.1 & 0.58 \\
\hline & & $60-80$ & n.a. & & & & & & & & & & & & \\
\hline & \multirow{4}{*}{ Quantitativefeedingrate } & total & 0.906 & 0.005 & & & -0.021 & & & & & & & -26.3 & \\
\hline & & $0-30$ & 1.243 & & & & -0.027 & & & & & 0.00914 & & -28.9 & \\
\hline & & $30-60$ & 0.953 & 0.007 & & & -0.027 & & & & & & & -20.5 & \\
\hline & & $60-80$ & n.a. & & & & & & & & & & & & \\
\hline
\end{tabular}


Table S5. Generalized linear models for litter decomposition, expressed as percent, derived using as explanatory variables the soil properties values measured in the fall sampling.

\begin{tabular}{|c|c|c|c|c|c|c|c|c|c|}
\hline \multirow{2}{*}{ Response variable } & \multicolumn{9}{|c|}{ Explanatory variable coefficients } \\
\hline & intercept & biochar & $\log M C B$ & clay & $p H$ & SOC & $\mathrm{Cl}$ & AICc & $r^{2}$ \\
\hline 2-mmmesh litterbags & -1.235 & 0.002 & & & 0.259 & & -0.002 & -62.7 & 0.72 \\
\hline 0.16-mmmesh litterbags & 0.179 & & 0.063 & 0.007 & & 0.044 & & -65.2 & 0.74 \\
\hline
\end{tabular}


Table S6. Generalized linear models for litter mineralization rates, expressed as $\mathrm{mg} \mathrm{kg}^{-1} \cdot \mathrm{day}^{-1}$, using as explanatory variables those collected on the summer sampling, when this assay was carried out. All the parameters are significantin itselfin the model except those indicated as (ns).

\begin{tabular}{|c|c|c|c|c|c|c|c|c|c|}
\hline \multirow[t]{2}{*}{$\begin{array}{l}\text { Response } \\
\text { variable }\end{array}$} & \multicolumn{9}{|c|}{ Explanatory variable coefficients } \\
\hline & intercept & $\log M C B$ & moisture & loam & pH.summer & PO4.summer & Cl.summer & $A I C$ & $r 2$ \\
\hline P-PO4 & 0.099 & & -0.005 & & & & -0.003 & -74.2 & 0.46 \\
\hline Cl & 9.645 & & & & -1.379 & 0.796 & & -24.1 & 0.76 \\
\hline N-NO2+NO3 & 0.039 & $-0.029(n s)$ & & & & 0.093 & & -55.8 & 0.38 \\
\hline N-NH4 & -0.084 & 0.024 & & & & 0.051 & & -103.7 & 0.70 \\
\hline S-SO4 & 1.321 & & & & -0.204 & & & -61.9 & 0.57 \\
\hline $\mathrm{C}-\mathrm{CO} 2$ & -0.163 & 0.038 & & $0.002(\mathrm{~ns})$ & & & & -84.3 & 0.51 \\
\hline
\end{tabular}


Figure S1. Mean soil soluble ion content in summer (black bars) and fall (white bars), together with the standard deviation (n=3 plots). Asterisks indicate significant differences in the values measured in the biochar-amended plots compared to control plots $\left(0 \mathrm{tha}{ }^{-1}\right)$.
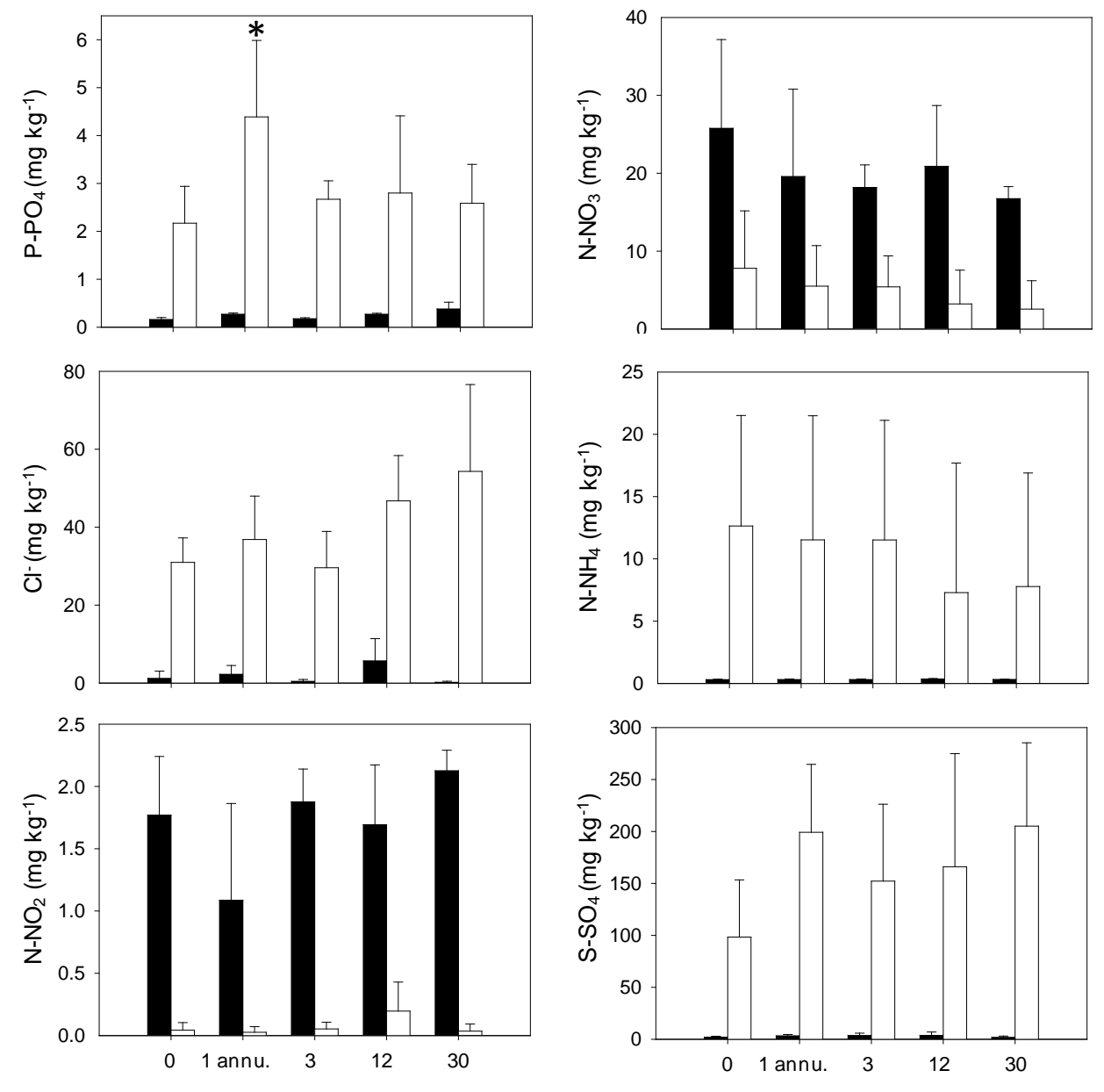

Biochar rate $\left(\mathrm{t} \mathrm{ha}{ }^{-1}\right)$ 